\title{
Microparticle and Atherothrombotic Diseases
}

\author{
Shosaku Nomura
}

First Department of Internal Medicine, Kansai Medical University, Osaka, Japan

\begin{abstract}
Microparticles (MPs) are small membrane vesicles that are released from many different cell types by exocytotic budding of the plasma membrane in response to cellular activation or apoptosis. MPs may be involved in both physiological processes and clinical treatments because they express phospholipids, which function as procoagulants. Elevated levels of platelet-derived MPs, endothelial cell-derived MPs, and monocyte-derived MPs are observed in almost all thrombotic diseases occurring in venous and arterial beds. Several studies have shown that the quantity, cellular origin, and composition of circulating MPs depend on the type of disease, the disease state, and medical treatment. Although MPs were initially thought to be small particles with only procoagulant activity, they are now known to have many different functions. An increasing number of studies have identified new implications of elevated MPs in clinical disorders. On the basis of evidence available till date, the present review suggests that MPs may be a useful biomarker in identifying atherothrombosis.
\end{abstract}

J Atheroscler Thromb, 2016; 23: 1-9.

Key words: Microparticle, Platelet, Endothelial cell, Procoagulant activity, Atherothrombosis

\section{Microparticle}

Microparticles (MPs) are small membrane vesicles that are released from many different cell types by exocytotic budding of the plasma membrane in response to cellular activation or apoptosis ${ }^{1-3)}$. MPs are generally measured using flow cytometry, and they can range in size from $0.1 \mu \mathrm{m}$ to $1.0 \mu \mathrm{m}^{1,2)}$. MPs disseminate various bioactive effectors originating from the parent cells. Therefore, MPs can alter vascular function and may induce biological responses involved in vascular homeostasis ${ }^{2)}$. Most MPs in human blood originate from platelets (platelet-derived MPs, abbreviated PDMPs). PDMPs contain various glycoproteins (GPs) such as GPIIb/IIIa or GPIb/IX ${ }^{1,2)}$. MPs are also released from leukocytes, erythrocytes, endothelial cells, smooth muscle cells (SMCs), and cancer cells ${ }^{1-4)}$. Elevated MP levels are documented in almost all thrombotic diseases occurring in venous and arterial beds ${ }^{5-7)}$. Elevated levels of MPs have also been associ-

Address for correspondence: Shosaku Nomura, First Department of Internal medicine, Kansai Medical University, 2-3-1 Shin-machi, Hirakata, Osaka 573-1191, Japan

E-mail: nomurash@hirakata.kmu.ac.jp

Received: July 24, 2015

Accepted for publication: July 29, 2015 ated with inflammation, cellular activation and dysfunction, angiogenesis, and cellular transport ${ }^{2,8-12)}$.

MPs contain functional cytoadhesions, bioactive phospholipids, cytoplasmic components, and various antigens that are characteristic of the state of the cell from which they originated and also of the type of stimulus ${ }^{13)}$. Some studies have analyzed the proteome of MPs and identified hundreds of proteins ${ }^{14,15)}$. Proteins from MPs may be useful biomarkers for various disease processes ${ }^{15}$. MPs are constitutively released from the cell surface, but their formation can be upregulated by cellular activation or apoptosis ${ }^{16,17)}$. After cellular activation or apoptosis is triggered, there is a rise in cytosolic calcium concentrations followed by cytoskeletal changes. Plasma membranes of cells contain different types of phospholipids. Although uncharged phospholipids are generally present in the outer leaflet of the membrane bilayer, the inner leaflet contains negatively charged aminophospholipids, such as phosphatidylserine (PS). During activation or apoptosis of the cell, there is a change in the membrane with alteration in the normal lipid bilayer, flip-flopping the internal PS to the external surface. Thus, PSexposing MPs may be released from the cells ${ }^{18)}$. 


\section{Shear Stress and MPs}

High shear stress can initiate platelet aggregation and shedding of procoagulant-containing PDMPs ${ }^{19,20)}$. Chow et al. ${ }^{21)}$ suggested that thrombin that is formed in the vicinity of primary hemostatic plugs in areas of elevated shear stress plays a key role in the propagation of thrombi by potentiating shear-induced PDMP generation. Furthermore, platelet GPs and specific receptors can be involved in high shear stress-induced PDMP formation ${ }^{19,22-24)}$. Miyazaki et al. ${ }^{19)}$ examined the mechanisms involved in PDMP production induced by high shear stress, and they showed that binding of von Willebrand factor to GPIb, influx of extracellular calcium, and activation of platelet calpain were required to generate PDMPs under high shear stress conditions. In addition, Reininger et al. ${ }^{24)}$ reported that the GPIb receptor mediates adhesion to von Willebrand factor, and under hydrodynamic flow, stretching of the platelet membrane occurs, followed by separation of areas of tethered membranes and production of MPs. Shear stress is also involved in the generation of endothelial cell-derived MPs (EDMP) because it is a major determinant of endothelial apoptosis $^{25,26)}$. Flow-induced increase in laminar shear stress is a potent physiological stimulant, which exerts atheroprotective effects in the vasculature ${ }^{27)}$. Exercisemediated wall shear stress increases mitochondrial biogenesis in vascular endothelium, decreasing the level of released $\mathrm{EDMP}^{28,29)}$.

\section{Tissue Factor and MPs}

MPs were initially thought to be related to diseases because they express phospholipids, which are procoagulants. These MPs support generation of thrombin and could be involved in diffuse intravascular coagulation occurring in disease states. However, such a coagulation system is activated not only in disease states but also in healthy individuals. Berckmans et al. ${ }^{30)}$ reported that MPs circulate in the blood of healthy humans and support low-grade thrombin generation. Sinauridze et al. ${ }^{31)}$ reported that PDMPs have 50 - to 100-fold higher specific procoagulant activity than activated platelets. Exposure of PS not only facilitates formation of coagulation complexes, but it also promotes the ability of TF to initiate coagulation ${ }^{32)}$. MPs support coagulation by factor (F)VII/TF-dependent and independent pathways ${ }^{33)}$. During vascular damage, blood contacts extravascular TF, resulting in extrinsic coagulation activation and formation of fibrin. Indeed, TF can be activated upon adhesion and fusion of MPs to activated platelets.
Several studies revealed that stimulation by tumor necrosis factor (TNF)- $\alpha$, lipopolysaccharide, or oxidized low-density lipoprotein in cultured human umbilical vein endothelial cells results in an increase in release of EDMPs expressing surface $\mathrm{TF}^{34-36)}$. The addition of increasing concentrations of these EDMPs to a coagulation assay reduces the plasma clotting time. This effect is not observed in FVII-deficient plasma, indicating that procoagulant activity of EDMPs is FVII/TF dependent in such situations. Interestingly, a subset of EDMPs bearing von Willebrand factor appears to be able to induce platelet aggregation $^{37)}$.

Monocyte-derived MPs (MDMPs) also contribute to the development of platelets and fibrin-rich thrombus at the sites of vascular injury, through the recruitment of cells and accumulation of TF. MDMPs express the P-selectin glycoprotein ligand-1 and $\mathrm{TF}^{38)}$. The binding of these MDMPs to P-selectin on activated endothelial cells on activated platelets in the developing thrombus may promote TF accumulation and localized thrombin generation. Subsequently, activated platelets expose $\mathrm{P}$-selectin and are capable of capturing TF-exposing MDMPs via P-selectin glycoprotein ligand-1. Consequently, MP-associated TF becomes rapidly deposited at the site of the developing thrombus. DelConde et al. ${ }^{39)}$ showed in vitro that fusion of membranes of TF-exposing MPs and activated platelets results in the transfer of TF in platelet membranes. This fusion results in co-localization of $\mathrm{TF}$ and coagulation factors, thus promoting a more efficient initiation and propagation of coagulation.

At the MP surface, the presence of proteins inhibiting coagulation, such as TF pathway inhibitor, protein $\mathrm{C}$, or thrombomodulin, increases the possibility of eventual contribution of MPs to an anticoagulant pathway ${ }^{40,41)}$. Although TF is exposed by MDMPs, TF activity is markedly inhibited by the MP-associated tissue factor pathway inhibitor (TFPI). In storage-induced PDMPs, $10 \%$ of which contain TF, TFdependent thrombin generation can only be observed in plasma in which TFPI is neutralized ${ }^{39)}$. A balance between TF and TFPI at the MP surface is probably an important feature in the initiation of blood coagulation, and higher levels of MPs containing TF possibly overcome the TFPI anticoagulant pathway ${ }^{40)}$.

There exist a large number of target antigens for EDMP measurement compared with antigens available for identifying cells ${ }^{2,3)}$. This suggests that EDMP involves functional molecules related to endothelial cells (Fig. 1). In particular, EDMP inherit the anticoagulant ability that is the most important function of endothelial cells ${ }^{4,13,17,26)}$. Researchers have also inves- 


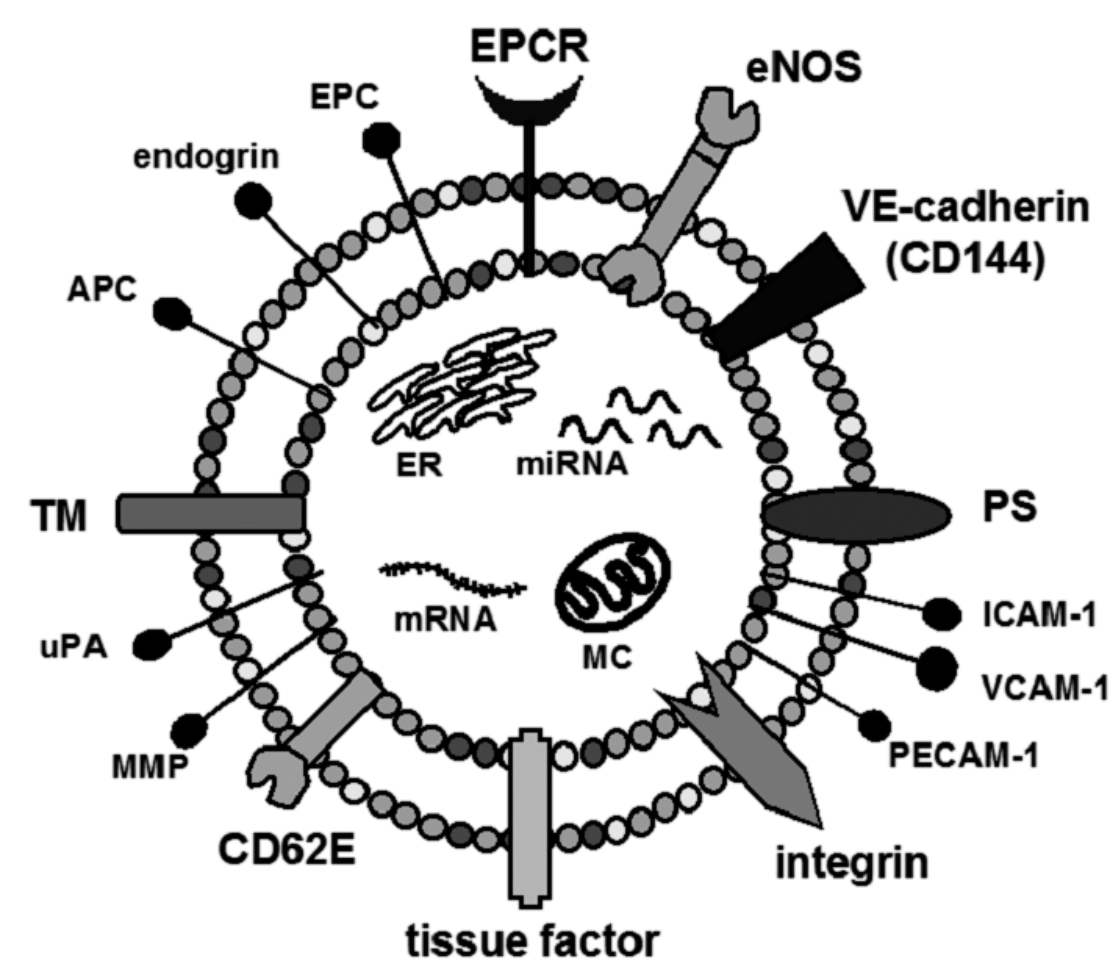

Fig. 1. Target antigens for EDMP

EDMP involves functional molecules related to endothelial cells. EPCR: endothelial protein $\mathrm{C}$ receptor, eNOS: endothelial nitric oxide synthase, PS: phosphatidylserine, ICAM-1: intracellular cell adhesion molecule-1, VCAM-1: vascular cell adhesion molecule-1, PECAM-1: platelet endothelial cell adhesion molecule-1, MMP: matrix metalloproteinase, uPA: urokinase-type plasminogen activator, TM: thrombomodulin, APC: activated protein $\mathrm{C}, \mathrm{EPC}$ : endothelial protein $\mathrm{C}, \mathrm{MC}$ : mitochondria, ER: endoplasmic reticulum, miRNA: micro RNA, mRNA: messenger RNA

tigated the effect of activated protein $\mathrm{C}$, which has anticoagulant and anti-inflammatory properties, on endothelial cells and EDMP formation ${ }^{411}$. Cultured endothelial cells exposed to activated protein $\mathrm{C}$ release EDMP with membrane-bound endothelial protein $\mathrm{C}$ receptor. Activated protein $\mathrm{C}$ that is bound to this receptor retains its anticoagulant activity, that is, its ability to inhibit the formation of thrombin ${ }^{41)}$.

\section{Identification of MPs}

An identification method for MPs is important for clinical studies on MPs. Appropriate sampling conditions, processing, and storage of samples are essential $^{1,2)}$. MPs can be directly quantified in plateletpoor plasma, obtained by serial centrifugation of citrated whole blood. Alternatively, washed MPs can be isolated from platelet-poor plasma by ultracentrifugation before resuspension and analysis. The most widely used method for studying MPs is flow cytometry because of its simplicity and the extent of informa- tion that can be obtained from the population under study ${ }^{42)}$.

The enzyme-linked immunosorbent assay (ELISA) is an easier and reproducible PDMP method ${ }^{43,44)}$. When using ELISA, PDMPs may be quantitated with reference to a standard curve. This method will hopefully contribute toward the understanding of participation of PDMPs in the clinical setting, if antibodies that are reactive with platelet activation markers, such as P-selectin and soluble CD40 ligand, are used. One of the problems associated with the ELISA is the possibility that it contains soluble GPs, such as the GPIb/ IX/V complex. Ueba et al. ${ }^{45-48)}$ measured circulating PDMPs in healthy Japanese individuals using the ELISA, and they suggested that PDMPs were positively associated with the level of metabolic syndrome. The use of MP quantification as a clinical tool is still debatable. A large-scale clinical trial for various thrombotic diseases using ELISA kits was performed in $\operatorname{Japan}^{49)}$. 


\section{Atherothrombosis and MPs}

Production of PDMPs, EDMPs, and leukocytederived MPs can be increased by inflammatory conditions ${ }^{50,51)}$. MPs formed by in vivo stimulation with a chemotactic peptide in healthy volunteers were able to induce IL-6 and monocyte chemoattractant protein (MCP)-1 release, as well as TF expression, by endothelial cells in vitro. A major feature in atherosclerosis is adhesion of monocytes to endothelial cells, followed by subendothelial transmigration. Cytokines, such as IL- $1 \beta$ and TNF- $\alpha$, affect this process by inducing synthesis or upregulation of leukocyte-endothelial adhesion molecules. In vitro stimulation of monocytes and endothelial cells by high shear stress-induced PDMPs results in significantly increased production of Il- 8 , IL- $1 \beta$, and TNF- $\alpha^{52)}$. Furthermore, treatment of endothelial cells and monocytes with PDMPs prior to co-incubation modulates monocyte-endothelial cell interactions by increasing the expression of adhesion molecules on both cell types ${ }^{52}$. Recently, some associations between PDMP levels and clinical outcomes in critically ill patients have also been evaluated, in addition to the importance of PDMPs in inflammation ${ }^{53)}$.

Circulating MPs of platelet and leukocytic origins promotes recruitment of inflammatory cells and induces cellular adhesiveness through upregulation of cytokines and cytoadhesions in endothelial cells and monocytes ${ }^{54)}$. Under high shear stress conditions, PDMP rolling enables delivery of RANTES to inflamed endothelium, thus favoring adhesion of monocytes and infiltration of plaques ${ }^{55}$. Development and progression of atherosclerotic plaques are associated with apoptotic cell death, explaining the presence of a considerable amount of procoagulant MPs in plaques ${ }^{4}$. Furthermore, enhanced apoptosis or activation of leukocytes, SMCs, and endothelium contribute to accumulation of MPs, 56). Compared with their circulating counterpart, MPs trapped in the plaque are present at much higher concentrations and display higher thrombogenic potential. In plaques, most of these MPs are from activated leukocytes, a hallmark of inflammation, and from erythrocytes, indicating the occurrence of intraplaque hemorrhage, which is a marker of vulnerability of plaques ${ }^{56)}$. Atherosclerotic plaques also contain a substantial amount of SMCderived MPs and EDMPs ${ }^{4}$. MPs not only contribute to plaque thrombogenicity but can also contribute to instability by mediating the recruitment of inflammatory cells. Therefore, circulating MPs can result in vascular inflammation, endothelial dysfunction, leukocyte adhesion, and recruitment. This could contribute to plaque growth or stent-induced vascular inflamma- tion because MPs convey biological effectors ${ }^{57)}$.

Oxidative stress, caused by reactive oxygen species (ROS), plays an important role in the pathogenesis of various diseases including atherothrombosis ${ }^{58,59)}$. Recent reports have also indicated that oxidative stress increases the levels of various MPs in circulation ${ }^{60,61)}$. Xanthin oxidase is among the major enzymatic sources of ROS, whereas anti-xanthin oxidase inhibitor can reduce the activity of $\operatorname{ROS}^{58)}$. In addition, Nishizawa et al. ${ }^{62)}$ reported that anti-xanthin oxidase inhibitor reduced PDMP levels in patients with hyperuricemia.

\section{Cardiovascular Diseases}

Procoagulant MPs have been implicated in the development and progression of atherosclerosis, the underlying cause of cardiovascular diseases ${ }^{63}$, 64 ). In particular, EDMP levels are higher in patients with acute coronary syndrome compared with patients with stable anginal symptoms or control patients ${ }^{65}$. Moreover, EDMP levels are higher in high-risk coronary lesions compared with low-risk lesions ${ }^{66}$. These findings indicate the participation of procoagulant EDMPs according to the degree of acute vascular injury and inflammation at the time of measurement. However, MPs do not always play a procoagulant role in cardiovascular diseases. For example, Steppich et al. ${ }^{37)}$ reported that in acute myocardial infarction, some MPs may have an anticoagulant function through expression of TFPI and reduction of TF-dependent thrombin generation, which may help limit thrombus formation. EDMPs may also possess anticoagulant properties, dependent on the presence of thrombomodulin and endothelial protein $C$ receptor ${ }^{4,67,68)}$.

A number of cytokines can induce procoagulant activity in leukocytes ${ }^{69)}$. A proinflammatory member of the $\mathrm{C}-\mathrm{C}$ chemokine family, RANTES, is a potent chemoattractant of memory T-lymphocytes, monocytes, eosinophils, and basophils. Several previous studies have suggested that RANTES is an inflammatory mediator in cardiovascular disease ${ }^{5,48,70)}$. In addition, the presence of RANTES may predict restenosis after percutaneous coronary intervention in patients with stable angina ${ }^{71,72)}$. PDMPs also relate to the levels of RANTES $^{5,44,55)}$ and are associated with atherosclerotic events after percutaneous coronary intervention ${ }^{73)}$. Postmenopausal women are at an increased risk of cardiovascular disease. One study reported a correlation between increased PDMP levels and early stage coronary artery calcification in menopausal women ${ }^{74)}$. Psoriasis is also a risk factor for cardiovascular disease because it is an immune-mediated inflammatory skin disease associated with systemic inflammation ${ }^{75)}$. 


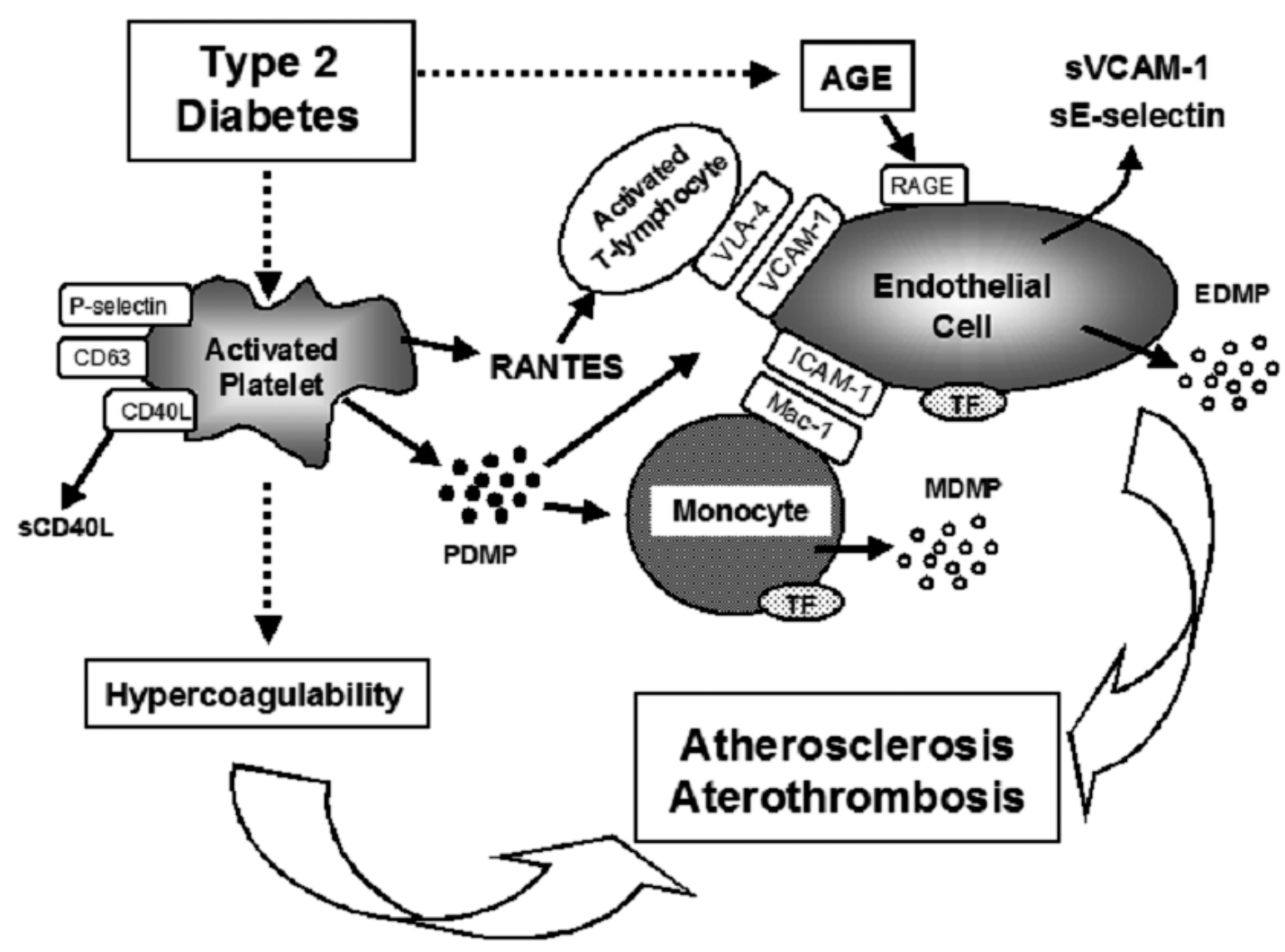

Fig. 2. Role of MPs in atherosclerosis and thrombosis in type 2 diabetes

Production of PDMPs, MDMPs, and EDMPs can be increased in type 2 diabetes. These MPs contribute to the generation of atherothrombosis in type 2 diabetes. Mac-1: $\beta-2$ integrin family in monocyte (CD11b/CD18), ICAM-1: intercellular adhesion molecule-1, VCAM-1: vascular cell adhesion molecule-1, VLA-4: very lated antigen-4, AGE: advanced glycation end products, RAGE: receptor for AGEs, TF: tissue factor, RANTES: regulated on activation, normal $T$ cell expressed and secreted, CD40L: CD40 ligand

Recently, Chandrashekar et al. ${ }^{76)}$ reported that PDMP levels were significantly elevated in patients with psoriasis.

\section{Diabetes Mellitus}

Diabetes mellitus is the main risk factor associated with atherosclerosis. MPs are elevated in diabetic patients, and interestingly the MP phenotype may vary within the type of diabetes. Some studies have found differences in the MP profile in relation to the disease type and the presence or absence of MPs ${ }^{2,3,77)}$. Sabatier et al ${ }^{77)}$ reported that in type 1 diabetes, the procoagulant potential of MPs, as measured by a prothrombinase assay, was elevated and correlated with the degree of glycemic control. However, in type 2 diabetes, although total numbers of MPs were elevated, there was no associated increase in their procoagulant potential. A few studies on the potential role of PDMPs in diabetic complications have been reported ${ }^{78-80)}$. In addition, both PDMPs and MDMPs are correlated with diabetic complications, including the extent of diabetic retinopathy, which is associated with microvascular damage ${ }^{81-87)}$. Elevated EDMP levels are predictive of coronary artery lesions and are a more significant independent risk factor than the duration of diabetic disease, lipid levels, or presence of hypertension $^{88)}$. Interestingly, elevated EDMP levels are predictive in identifying a subpopulation of diabetic patients without typical anginal symptoms who have angiographic evidence of coronary artery disease. Therefore, in patients with type 2 diabetes mellitus, the level of circulating EDMPs increases with the severity of the disease $^{89,90)}$. In conclusion, production of PDMP, MDMP, and EDMP can be increased in type 2 diabetes, and these MPs contribute to the generation of atherothrombosis in type 2 diabetes $^{91)}$ (Fig. 2). 


\section{Conclusion}

This manuscript summarizes the literature till date on MPs, including a growing list of clinical disorders that are associated with elevated MP levels. MPs were initially thought to be small particles with procoagulant activity. However, increasing number of researchers are investigating the possibility that MPs evoke cellular responses in the immediate microenvironments where they are formed.

\section{Acknowledgments}

This study was supported in part by research grants from the Japanese Ministry of Health, Labour and Welfare and the Japanese Ministry of Education, Science, Sports and Culture.

\section{Competing Interests}

None of the authors disclose any financial of personal relationships with other people or organizations that could inappropriately influence (bias) their work. Examples of potential conflicts of interest include employment, consultancies, stock ownership, honoraria, paidexpert testimony, patent applications/registrations, and grants or other funding.

\section{References}

1) Nomura S, Ozaki Y, Ikeda Y: Function and role of microparticles in various clinical settings. Thromb Res, 2008; 123: 8-23

2) Nomura $S$, Shimizu M: Clinical significance of procoagulant microparticles. J Intens Care, 2015; 3: 2-11

3) Vajen T, Mause SF, Koenen RR: Microvesicles from platelets: novel drivers of vascular inflammation. Thromb Haemost, 2015; 114: 228-236

4) Angelillo-Scherrer A: Leukocyte-derived microparticles in vascular homeostasis. Cir Res, 2012; 110: 356-369

5) Matsumoto N, Nomura S, Kamihata H, Kimura Y, Iwasaka T: Increased level of oxidized LDL-dependent monocyte-derived microparticles in acute coronary syndrome. Thromb Haemost, 2004; 91: 146-154

6) Simak J, Gelderman MP, Yu H, Wright V, Baird AE: Circulating endothelial microparticles in acute ischemic stroke: a link to severity, lesion volume and outcome. J Thromb Haemost, 2006; 4: 1296-1302

7) Ederhy S, Di Angelantonio E, Mallat Z, Hugel B, Janower $S$, Meuleman C, Boccara F, Freyssinet JM, Tedgui A, Cohen A: Levels of circulating procoagulant microparticles in nonvalvular atrial fibrillation. Am J Cardiol, 2007; 100: 989-994

8) Kim HK, Song KS, Chung JH, Lee KR, Lee SN: Platelet microparticles induce angiogenesis in vitro. $\mathrm{Br} \mathrm{J}$ Haematol, 2004; 124: 376-384
9) Sinning JM, Losch J, Walenta K, Böhm M, Nickenig G, Werner N: Circulating CD31 ${ }^{+} /$AnnexinV $^{+}$microparticles correlate with cardiovascular outcomes. Eur Heart J, 2010; 32: 2034-2041

10) Wang JG, Geddings JE, Aleman MM, Cardenas JC, Chantrathammachart P, Williams JC, Kirchhofer D, Bogdanov VY, Bach RR, Rak J, Church FC, Wolberg AS, Pawlinski R, Key NS, Yeh JJ, Mackman N: Tumorderived tissue factor activates coagulation and enhances thrombosis in a mouse xenograft model of human pancreatic cancer. Blood, 2012; 119: 5543-5552

11) Suades R, Padró T, Alonso R, Mata P, Badimon L: Lipidlowering therapy with statins reduces microparticles chedding from endothelium, platelets and inflammatory cells. Thromb Haemost, 2013; 110: 366-377

12) Suades R, Padró T, Alonso R, López-Miranda J, Mata P, Badimon L: Circulating $\mathrm{CD} 45^{+} / \mathrm{CD}^{+}$lymphocytederived microparticles map lipid-rich atherosclerotic plaques in FH patients. Thromb Haemost, 2014; 111: $111-121$

13) Abid Hussein MN, Meesters EW, Osmanovic N, Romijn FP, Nieuwland R, Sturk A: Antigenic characterization of endothelial cell-derived microparticles and their detection ex vivo. J Thromb Haemost, 2003; 1: 2434-2443

14) Garcia BA, Smalley DM, Cho H, Shabanowitz J, Ley K, Hunt DF: The platelet microparticle proteome. J Proteome Res, 2005; 4: 1516-1521

15) Smalley DM, Root KE, Cho H, Ross MM, Ley K: Proteomic discovery of 21 proteins expressed in human plasma-derived but not platelet-derived microparticles. Thromb Haemost, 2007; 97: 67-80

16) Lynch SF, Ludlam CA: Plasma microparticles and vascular disorders. Br J Haematol, 2007; 137: 36-48

17) Sabatier F, Camoin-Jau L, Anfosso F, Sampol J, DignatGeorge F: Circulating endothelial cells, microparticles and progenitors: key players towards the definition of vascular competence. J Cell Med Med, 2009; 13: 454-471

18) Kaplan ZS, Jackson SP: The role of platelets in atherothrombosis. Hematology Am Soc Hematol Educ Program 2011; 2011: 51-61

19) Miyazaki Y, Nomura S, Miyake T, Kagawa H, Kitada C, Taniguchi H, Komiyama Y, Fujimura Y, Ikeda Y, Fukuhara S: High shear stress can initiate both platelet aggregation and shedding of procoagulant containing microparticles. Blood, 1996; 88: 3456-3464

20) Nomura S, Nakamura T, Cone J, Tandon NN, Kambayashi J: Cytometric analysis of high shear-induced platelet microparticles and effect of cytokines on microparticle generation. Cytometry, 2000; 40: 173-181

21) Chow TW, Hellums JD, Thiagarajan P: Thrombin receeptor activating peptide (SFLLRN) potentiates shearinduced platelet microvesiculation. J Lab Clin Med, 2000; 135: 66-72

22) Goto S, Tamura N, Eto K, Ikeda Y, Handa S: Functional significance of adenosine 5'-diphosphate receptor (P2Y (12)) inplatelet activation initiated by binding of von Willebrand factor to platelet GPIb $\alpha$ induced by conditions of high shear rate. Circulation, 2002; 105: 2531-2536

23) Pontiggia L, Steiner B, Ulrichts H, Deckmyn H, Forestier $\mathrm{M}$, Beer JH: Platelet microparticle formation and throm- 
bin generation under high shear are effectively suppressed by a monoclonal antibody against GPIb $\alpha$. Thromb Haemost, 2006; 96: 774-780

24) Reininger AJ, Heijnen HF, Schumann H, Specht HM, Schramm W, Ruggeri ZM: Mechanism of platelet adhesion to von Willebrand factor and microparticle formation under high shear stress. Blood, 2006; 107: 35373545

25) Sapet C, Simoncini S, Loriod B, Puthier D, Sampol J, Nguyen C, Dignat-George F, Anfosso F: Thrombininduced endothelial microparticle generation: identification of a novel pathway involving ROCK-II activation by caspase-2. Blood, 2006; 108: 1868-1876

26) Boulanger CM, Amabile N, Guerin AP, Pannier B, Leroyer AS, Mallat CN, Tedgui A, London GM: In vivo shear stress determines circulating levels of endothelial microparticles in end-stage renal disease. Hypertension, 2007; 49: 902-908

27) Cion AC, Ramkhelawon B, Loyer X, Chironi G, Devue C, Loirand G, Tedgui A, Lehoux S, Boulanger CM: Shear stress regulates endothelial microparticle release. Cir Res, 2013; 112: 1323-1333

28) Kim B, Lee H, Kawata K, Park JY: Exercise-mediated wall shear stress increases mitochondrial biogenesis in vascular endothelium. PLoS One, 2014; 9: e111409

29) Kim JS, Kim B, Lee H, Thakkar S, Babbitt DM, Eguchi $S$, Brown MD, Park JY: Shear stress-induced mitochondrial biogenesis decreases the release of microparticles from endothelial cells. Am J Physiol Heart Circ Physiol, 2015; 309: H425-H433

30) Berckmans RJ, Nieuwland R, Boing AN, Romijn FP, Hack CE, Sturk A: Cell-derived microparticles circulate in healthy humans and support low grade thrombin generation. Thromb Haemost, 2001; 85: 639-646

31) Sinauridze EI, Kireev DA, Popenko NY, Pichugin AV, Panteleev MA, Krymskaya OV, Ataullakhanov FI: Platelet microparticle membranes have 50 - to 100 -fold higher specific procoagulant activity than activated platelets. Thromb Haemost, 2007; 97: 425-434

32) Wolberg AS, Monroe DM, Roberts HR, Hoffman MR: Tissue factor de-encryption: ionophore treatment induces changes in tissue factor activity by phosphatidylserinedependent and -independent mechanisms. Blood Coagul Fibrinolysis, 1999; 10: 201-210

33) Khan MM, Hattori T, Niewiarowski S, Edmunds LHJr, Colman RW: Truncated and microparticle-free soluble tissue factor bound to peripheral monocytes preferentially activated factor VII. Thromb Haemost, 2006; 95: 462468

34) Kagawa H, Komiyama $Y$, Nakamura S, Miyake $T$, Miyazaki Y, Hamamoto K, Masuda M, Takahashi H, Nomura S, Fukuhara S: Expression of functional tissue factor on small vesicles of lipopolysaccharide-stimulated human vascular endothelial cells. Thromb Res, 1998; 91: 297-304

35) Combes V, Simon AC, Grau GE, Arnoux D, Camoin L, Sabatier F, Mutin M, Sanmarco M, Sampol J, DignatGeorge F: In vitro generation of endothelial microparticles and possible prothrombotic activity in patients with lupus anticoagulant. J Clin Invest, 1999; 104: 93-102
36) Nomura $S$, Shouzu A, Omoto $S$, Nishikawa M, Iwasaka $T$, Fukuhara S: Activated platelets and oxidized LDL induce endothelial membrane vesiculation: clinical significance of endothelial cell-derived microparticles in patients with type 2 diabetes. Clin Appl Thromb Hemost, 2004; 10: 205-215

37) Jy W, Jimenez JJ, Mauro LM, Hoestman LL, Cheng P, Ahn ER, Bidot CJ, Ahn YS: Endothelial microparticles induce formation of platelet aggregates via a vonWillebrand factor/ristocetin dependent pathway, rendering them resistant to dissociation. J Thromb Haemost, 2005; 3: 1301-1308

38) Falati S, Liu Q, Gross P, Merrill-Skoloff G, Chou J, Vandendries E, Celi A, Croce K, Furie BC, Furie B: Accumulation of tissue factor into developing thrombi in vivo is dependent upon microparticle P-selectin glycoprotein ligand 1 and platelet P-selectin. J Exp Med, 2003; 197: $1585-1598$

39) Del Conde I, Shrimpton CN, Thiagarajan P, López JA: Tissue-factor- bearing microvesicles arise from lipid rafts and fuse with activated platelets to initiate coagulation. Blood, 2005; 106: 1604-1611

40) Steppich B, Mattisek C, Sobczyk D, Kastrati A, Schömig A, Ott I: Tissue factor pathway inhibitor on circulating microparticles in acute myocardial infarction. Thromb Haemost, 2005; 93: 35-39

41) Perez-Casal M, Downey C, Fukudome K, Marx G, Toh $\mathrm{CH}$ : Activated protein $\mathrm{C}$ induces the release of microparticle-associated endothelial protein $\mathrm{C}$ receptor. Blood, 2005; 105: 1515-1522

42) Shantsila E, Montoro-Garcia S, Gallego P, Lip GYH: Circulating microparticles: challenges and perspectives of flow cytometric assessment. Thromb Haemost, 2014; 111: 1009-1014

43) Osumi K, Ozeki Y, Saito S, Nagamura Y, Ito H, Kimura Y, Ogura H, Nomura S: Development and assesssment of enzyme immunoassay for platelet-derived microparticles. Thromb Haemost, 2001; 85: 326-330

44) Nomura $S$, Uehata $S$, Saito S, Osumi K, Ozeki Y, Kimura Y: Enzyme immunoassay detection of platelet-derived microparticles and RANTES in acute coronary syndrome. Thromb Haemost, 2003; 89: 506-512

45) Ueba T, Haze T, Sugiyama M, Higuchi M, Asayama H, Karitani Y, Nishikawa T, Yamashita K, Nagami S, Nakayama T, Kanatani K, Nomura S: Level, distribution and correlates of platelet-derived microparticles in healthy Japanese people with special reference to the metabolic syndrome. Thromb Haemost, 2008; 100: 280-285

46) Ueba T, Nomura $S$, Inami N, Nishikawa T, Kajiwara M, Iwata R, Yamashita K: Correlation and association of plasma interleukin-6 and plasma platelet-derived microparticles, markers of activated platelets, in healthy individuals. Thromb Res, 2010; 125: e329-e334

47) Ueba T, Nomura $S$, Inami N, Nishikawa T, Kajiwara $M$, Iwata R, Yamashita K: Plasma level of platelet-derived microparticles is associated with coronary heart disease risk score in healthy men. J Atheroscler Thromb, 2010; 17: 342-349

48) Ueba T, Nomura $S$, Inami N, Yokoi T, Inoue T: Elevated RANTES levels associated with metabolic syndrome and 
correlated with activated platelets associated markers in healthy younger men. Clin Appl Thromb Hemost, 2014; 20: 813-818

49) Nomura S, Shouzu A, Taomoto K, Togane Y, Goto S, Ozaki Y, Uchiyama S, Ikeda Y: Assessment of an ELISA kit for platelet-derived microparticles by joint research at many institutes in Japan. J Atheroscler Thromb, 2009; 16: 878-887

50) Joop K, Berckmans RJ, Nieuwland R, Berkhout J, Romijin FP, Hack CE, Sturk A: Microparticles from patients with multiple organ dysfunction syndrome and sepsis support coagulation through multiple mechanisms. Thromb Haemost, 2001; 85: 810-820

51) Daniel L, Fakhouri F, Joly D, Mouthon L, Nusbaum P, Grunfeld JP, Schifferli J, Guillevin L, Lesavre P, Halbwachs-Mecarelli L: Increase of circulating neutrophil and platelet microparticles during acute vasculitis and hemodialysis. Kidney Int, 2006; 69: 1416-1423

52) Keuren JF, Magdeleyns EJ, Govers-Riemslag JW, Lindhout T, Cuvers J: Effects of strage-induced platelet microparticles on the initiation and propagation phase of blood coagulation. Br J Haematol, 2006; 134: 307-313

53) Ohuchi $M$, Fujino $K$, Kishimoto $T$, Yamane $T$, Hamamoto T, Tabata T, Tsujita Y, Matsushita M, Takahashi K, Matsumura K, Eguchi Y: Association of the plasma platelet-derived microparticles to platelet count ratio with hospital mortality and disseminated intravascular coagulopathy in critically ill patients. J Atheroscler Thromb, 2015; 22: 773-782

54) Barry OP, FitzGerald GA: Mechanisms of cellular activation by platelet microparticles. Thromb Haemost, 1999; 82: 794-800

55) Mause SF, von Hundelshausen P, Zernecke A, Koenen RR, Weber C: Platelet microparticles: a transcellular derivery system for RANTES promoting monocyte recruitment on endothelium. Arterioscler Thromb Vasc Biol, 2005; 25: $1512-1518$

56) Leroyer AS, Isobe $H$, Lesèche $G$, Castier $Y$, Wassef $M$, Mallat Z, Binder BR, Tedgui A, Boulanger CM: Cellular origins and thrombogenic activity of microparticles isolated from human atherosclerotic plaques. J Am Coll Cardiol, 2007; 49: 772-777

57) Chironi G, Simon A, Hugel B, Del Pino M, Gariepy J, Freyssinet JM, Tedgui A: Circulating leukocyte-derived microparticles predict subclinical atherosclerosis in asymptomatic subjects. Arterioscler Thromb Vasc Biol, 2006; 26: 2775-2780

58) Berry CE, Hare JM: Xanthine oxidoreductase and cardiovascular disease: molecular mechanisms and pathophysiological implications. J Physiol, 2004; 555: 589-606

59) Kushiyama A, Okubo H, Sakoda H, Kikuchi T, Fujishiro M, Sato H, Kushiyama S, Iwashita M, Nishimura F, Fukushima T, Nakatsu Y, Kamata H, Kawazu S, Higashi Y, Kurihara H, Asano T: Xanthine oxidoreductase is involved in macrophage foam cell formation and atherosclerosis development. Arterioscler Thromb Vasc Biol, 2012; 32: 291-298

60) Hjuler Nielsen M, Irvine H, Vedel S, Raungaard B, BeckNielsen H, Hanberg A: Elevated atherosclerosis-related gene expression, monocyte activation and microparticle- release are related to increased lipoprotein-associated oxidative stress in familial hypercholesterolemia. PLoS One, 2015; 10: e0121516

61) Yang M, Bhopale VM, Thom SR: Separating the roles of nitrogen and oxygen in high pressure-induced bloodborne microparticle elevations, neutrophil activation and vascular injury in mice. J Appl Physiol, 2015; 119: 219222

62) Nishizawa T, Taniura T, Nomura S: Effects of febuxostat on platelet-derived microparticles and adiponectin in patients with hyperuricemia. Blood Coagl Fibrinolysis, 2015; 26: 887-892

63) Amabile N, Rautou PE, Tedgui A, Boulanger CM: Microparticles: key protagonists in cardiovascular disorders. Semin Thromb Hemost, 2010; 36: 907-916

64) Chen YL, Chen CH, Wallace CG, Wang HT, Yang CC, Yip HK: Levels of circulating microparticles in patients with chronic cardiorenal disease. J Atheroscler Thromb, 2015; 22: 247-256

65) Bernal-Mizrachi L, Jy W, Jimenez JJ, Pastor J, Mauro LM, Horstman LL, de Marchena E, Ahn YS: High levels of circulating endothelial microparticles in patients with acute coronary syndromes. Am Heart J, 2003; 145: $962-$ 970

66) Bernal-Mizrachi L, Jy W, Fierro C, Macdonough R, Velazques HA, Purow J, Jimenez JJ, Horstman LL, Ferreira A, de Marchena E, Ahn YS: Endothelial microparticles correlate with high-risk angiographic lesions in acute coronary syndromes. Int J Cardiol, 2004; 97: 439-446

67) Dignat-George F, Boulanger CM: The many faces of endothelial micropartcles. Arterioscler Thromb Vasc Biol, 2011; 31: 27-33

68) Curtis AM, Edelberg J, Jonas R, Rogers WT, Moore JS, Syed W, Mohler ER 3rd: Endothelial microparticles: sophisticated vesicles modulating vascular function. Vasc Med, 2013; 18: 204-214

69) Neuwmann FJ, Ott I, Marx N, Luther T, Kenngott S, Gawaz M, Kotzsch M, Schömig A: Effect of human recombinant interleukin-6 and interleukin-8 on monocyte procoagulat activity. Arterioscler Thromb Vasc Biol, 1997; 17: 3399-3405

70) Steppich BA, Moog P, Matissek C, Winiowski N, Kuhle J, Joghetaei N, Neumann FJ, Schomig A, Ott I: Cytokine profiles and $\mathrm{T}$ cell function in acute coronary syndrome. Atherosclerosis, 2007; 190: 443-451

71) Inami N, Nomura S, Manabe K, Kumura Y, Iwasaka T: Platelet-derived chemokine RANTES may be a sign of restenosis after percutaneous coronary intervention in patients with statble angina pectoris. Platelets, 2006; 17: 565-570

72) Inami N, Nomura S, Shimazu T, Manabe K, Kumura Y, Iwasaka T: Adiponectin incompletely prevent MCP-1-dependent restenosis after percutaneous coronary intervention in patients with coronary artery disease. J Thromb Thrombolysis, 2007; 24: 267-273

73) Namba M, Tanaka A, Shimada K, Ozaki Y, Uehata S, Sakamoto T, Nishida Y, Nomura S, Yoshikawa J: Circulating platelet-derived microparticles are associated with atherothrombotic events. A marker for vulnerable blood. Arterioscler Thromb Vasc Biol, 2007; 27: 255-256 
74) Jayachandran M, Litwiller RD, Owen WG, Heit JA, Behrenbeck T, Mulvagh SL, Araoz PA, Budoff MJ, Harman SM, Miller VM: Characterization of blood borne microparticles as markers of premature coronary calcification in newly menopausal women. Am J Physiol Heart Circ Physiol, 2008; 295: H931-H938

75) Saleh HM, Attia EA, Onsy AM, Saad AA, Abd Ellah MM: Platelet activation: a link between psoriasis per se and subclinical atherosclerosis--a case-control study. Br J Dermatol, 2013; 169: 68-75

76) Chandrashekar L, Rajappa M, Revathy G, Sundar I, Munisamy M, Ananthanarayanan PH, Thappa DM, Basu D: Is enhanced platelet activation the missing link leading to increased cardiovascular risk in psoriasis? Clin Chim Acta, 2015; 446: 181-185

77) Sabatier F, Darmon P, Hugel B, Combes V, Sanmarco M, Velut JG, Arnoux D, Charpiot P, Freyssinet JM, Oliver C, Sampol J, Dignat-George F: Type 1 and Type 2 diabetic patients display different patterns of cellular microparticles. Diabets, 2002; 51: 2840-2845

78) Nomura S, Shouzu A, Omoto S, Nishikawa M, Fukuhara $S$ : Significance of chemokines and activated platelets in patients with diabetes. Clin Exp Immunol, 2000; 121: 437-443

79) Nomura S, Kanazawa S, Fukuhara S: Effects of eicosapentaenoic acid on platelet activation markers and cell adhesion molecules in hyperlipidemic patients with type 2 diabetes mellitus. J Diabet Complicat, 2003; 17: 153-159

80) Ogata N, Imaizumi M, Nomura S, Shouzu A, Arichi M, Matsuoka M: Increased levels of platelet-derived microparticles in patients with diabetic retinopathy. Diabet Res Clin Pract, 2005; 68: 193-201

81) Omoto S, Nomura $S$, Shouzu A, Nishikawa M, Fukuhara $S$, Iwasaka T: Detection of monocyte-derived microparticles in patients with type II diabetes mellitus. Diabetologia, 2002; 45: 550-555

82) Nomura S, Kanazawa S, Fukuhara S: Effects of efonidipine on platelet and monocyte activation markers in hypertensive patients with and without type 2 diabetes mellitus. J Hum Hypertens, 2002; 16: 539-547

83) Nomura S, Takahashi N, Inami N, Kajiura T, Yamada K, Nakamori H, Tsuda N: Probucol and ticlopidine: effect on platelet and monocyte activation markers in hyperlipidemic patients with and without type 2 diabetes. Atherosclerosis, 2004; 174: 329-335

84) Nomura S, Shouzu A, Omoto S, Nishikawa M, Iwasaka T: Long-term treatment with nifedipine modilates procoagulant maekers and C-C chemokine in hypertensive patients with type 2 diabetes mellitus. Thromb Res, 2005; 115 : 277-285

85) Nomura $S$, Shouzu A, Omoto $S$, Nishikawa M, Fukuhara S, Iwasaka T: Effects of valsartan on monocyte/endothelial cell activation markers and adiponectin in hypertensive patients with type 2 diabetes mellitus. Thromb Res, 2006; 117: 385-392

86) Nomura S, Inami N, Kimura Y, Omoto S, Shouzu A, Nishikawa M, Iwasaka T: Effect of nifedipine on adiponectin in hypertensive patients with type 2 diabetes mellitus. J Hum Hypertens, 2007; 21: 38-44

87) Ogata N, Nomura S, Shouzu A, Imaizumi M, Arichi M, Matsumura M: Elevation of monocyte-derived microparticles in patients with diabetic retinopathy. Diabet Res Clin Pract, 2006; 73: 241-248

88) Koga H, Sugiyama SD, Kugiyama K, Watanabe K, Fukushima H, Tanaka T, Sakamoto T, Yoshimura M, Jinnouchi $\mathrm{H}$, Ogawa H: Elevated levels of VE-cadherin-positive endothelial microparticles in patients with type 2 diabetes mellitus and coronary artery disease. J Am Coll Cardiol, 2005; 45: 1622-1630

89) Curtis AM, Zhang L, Medenilla E, Gui M, Wilkinson PF, Hu E, Giri J, Doraiswamy V, Gunda S, Burgert ME, Moore JS, Edelberg JM, Mohler ER 3rd: Relationship of microparticles to progenitor cells as a measure of vascular health in a diabetic population. Cytometry B Clin Cytom, 2010; 78: 329-337

90) Tsimerman G, Roguin A, Bachar A, Melamed E, Brenner $B$, Aharon A: Involvement of microparticles in diabetic vascular conplications. Thromb Haemost, 2011; 106: 310-321

91) Nomura S, Inami N, Shouzu A, Urase F, Maeda Y: Correlation and association between plasma platelet-, monocyte- and endothelial cell-derived microparticles in hypertensive patients with type 2 diabetes mellitus. Platelet, 2009; 20: 406-414 